\title{
Regional Development of Tourism in Ponorogo Regency, East Java
}

\author{
Yusuf Adam Hilman * \\ Department of Social and Political Sciences, Muhammadiyah University of Ponorogo, Indonesia
}

\begin{abstract}
Ponorogo Regency in East Java has natural resources, as well as the potential typical culture, and a society that can be developed into tourism attractions. This study was aimed to assess these potentials that can be then optimally developed, with factors that support the construction of tourism in Regency of Ponorogo. In carrying out the development of tourism in Ponorogo, there are several constraint or barrier factors, including access to transportation facilities and infrastructure which are still minimum and not optimal, access of the road and cross facilities is still less than the expectation, make it difficult for visitors to access tourism in Ponorogo. To solve this problem, we should implement the good cooperations, for all parties to jointly together in solving those problems.
\end{abstract}

Keywords: community development, development of tourism, potential of the region.

\section{INTRODUCTION}

Since Nawacita concept is implemented by government era of Joko Widodo and Jusuf Kalla, the village recurs different superior, innovative and also creative program variants as successor program. They put the fundamental base on village's institutional strengthening in order to create a prosperous community [1].

Several factors trigger the emergence of various types of empowerment and development programs in the village area. The programs were related to the issued of village's act, which states that village as the source of funds from various allocation reached 2 (two) billion rupiah. In addition to this, the village also has the right to manage the funds independently and in accordance with the autonomy policy, one important thing that is listed in the regulation of the village is also obliged to do transparent, accountable, and systematic accountability through the accountability system which is managed online.

Seeing the phenomenon, a notion appeared on how the process related to the evaluation of the program that produced by the village. Thus it can inflict the double effect on the welfare of society, and also the program utilization that can be a self-sustaining program and its management can be maximized.

All this time, in running regulations on the village and regarding the utilization of village's funds, many experts believe that the village still

\footnotetext{
${ }^{*}$ Correspondence address:

Yusuf Adam Hilman

Email : 545471adamongis@gmail.com

Address : Jln. Pramuka, Gg. IV No. 04 Siman Ponorogo, East Java
}

has many deficiencies, including in the planning process, implementation of the program until the evaluation. Moreover, the lack of qualified human resources to run the programs leads to ineffective village's program.

The programs that normally used by the village, mostly construction, such as build the football field, volley field, the purchase of the arts, procurement of the village's health vehicle (mobile clinic), and lavatory, etc. However, with sufficient potential fund of the village, the programs more emphasize on greater involvement of all citizens to achieve the joint purposes.

A program that can be implemented by the village administration is the eco tourism program which insists on the exploration of local potential that existed in the village. It is expected easy for tourism sector in helping to increase the economy of village community, thus the village will be more independent without had to remove characteristic of the village, which tended to be traditional, agrarian or nautical, as well as their complex social system. The aim of the study was to analyze the potential of tourism attraction in Regency of Ponorogo.

\section{STUDY AREA}

Regency of Ponorogo is one of the areas that administratively part of East Java. The regency has some districts consisting of several villages (Fig. 1). Regency of Ponorogo has $1,371.78 \mathrm{~km}^{2}$ wide area which lies between $111^{\circ} 17^{\prime}-111^{\circ} 52^{\prime}$ East and $7^{\circ} 49^{\prime}-8^{\circ} 20^{\prime}$ South with altitude $92-$ 2,563 feet asl. Bordering of the area in the north is with Magetan and Nganjuk Regency, while in the east is Tulungagung and Trenggalek Regency, 
south with Pacitan Regency and west with of Pacitan Regency and Wonogiri Regency (Central Java). Seen from the state of geographical size, Regency of Ponorogo divided into two sub areas, i.e. highland area included Ngrayun, Sooko, Pulung and Ngebel District, while the rest of the area is lowland.

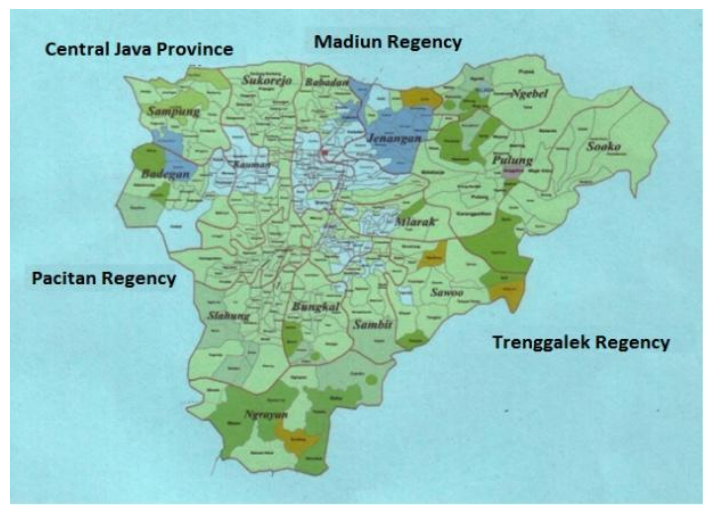

Figure 1. Map of Ponorogo Regency [2]

River that passed the area is $4-58 \mathrm{~km}$ long. The river functioned as a source of irrigation for agricultural land to the production of rice and horticulture. Most of the area was used for forestry or farming, and the rest used to tegal (garden), settlement and others.

Administratively, Ponorogo Regency divided into 21 districts and 305 villages. The total number of officials is 3,795 personal consisted of 301 head of villages, 265 secretary of village, head of subvillages 1,038 (called kamituwo) and 2,191 technical affairs officers. Each village was handled by 12 officers (average) to implement governmental activities at the village level [3]. Ideas about making tourism village in Ponorogo Regency certainly need innovation on the phase of preparation, mapping areas, an analysis of strength and weakness, and the village's tourism attractions accordance with the type of what is fitted to be applied in several villages in Ponorogo.

Tourist village is a rural area which offer the authenticity, both in terms of social and cultural, customary, daily activities, traditional architecture, the structure of spatial planning of the village which are presented in a form of integration between tourism components such as attraction, accommodation and supporting facilities [4]. There are two important components for tourism village, i.e. accommodation and attraction [5].

\section{Population of Ponorogo}

According to a socio economic survey in 2009, the district population in Ponorogo was 899,328 inhabitants. It is consisting of 456,023 men and 443,305 women, increased $0.38 \%$ from 2008 [6].

\section{POTENTIAL OF THE VILLAGES IN PONOROGO Agricultural Potential}

Ponorogo is geographically has agricultural potentials in various fields, such as farming in the form of paddy fields and also onion plants (Fig. 2). Ponorogo is one of the buffer zones of food in East Java, with rice-fields area 34,800 ha. It consisted of the area for technical irrigation 30,091 ha, the technical area of 625 ha, non technical 2,228 ha and rainfed paddy field area 1,856 ha. While the dry land of 102,378 ha area, $21.15 \%$ are used for settlements and building, $29.57 \%$ for orchards or fields, $45.85 \%$ to wood plantation and the remaining $3.43 \%$ used as community forest, plantation and other. Area for paddy field increased by $1.08 \%$ with production of $4,222,813$ quintal, increased compared to the previous year $3,942,780$ quintal [3].
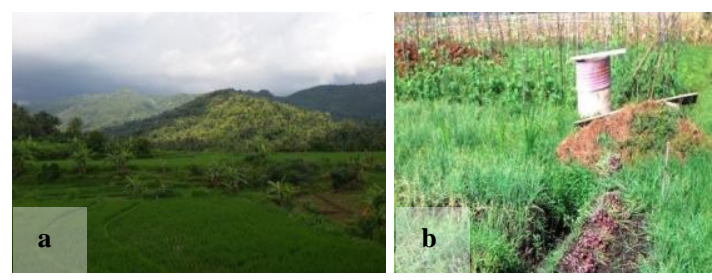

Figure 2. Rural Majority Farming of Ponorogo a) paddy field for rice cultivation [7], b) onion plant [8]

\section{Natural Resources Potential}

Geographically, Ponorogo Regency is fertile. This area consisted of areas with the contours of low or high altitude. This gives descriptions of natural resources in Ponorogo, in the form of: mountains, lake, hot springs, waterfall, natural rocks and several others of natural resources (Table 1).

\section{Cultural Potential}

Discussing about Ponorogo, it will associate to the well-known culture Art, i.e. Reog Ponorogo. Nevertheless, there is another art from Ponorogo Regency, i.e. the elephant art (Gajahan) which has unique and cultural value (Fig. 3).

\section{Religious Site}

In Ponorogo, Muslim residents was accounted for total 1,004,899, Christian 3,475, Catholic 3,428, Hindu 2,734, and Buddhism 5,872. From 
the distribution of community religion in Ponorogo, we can witness several religious relics [3] as shown in Figure 4.

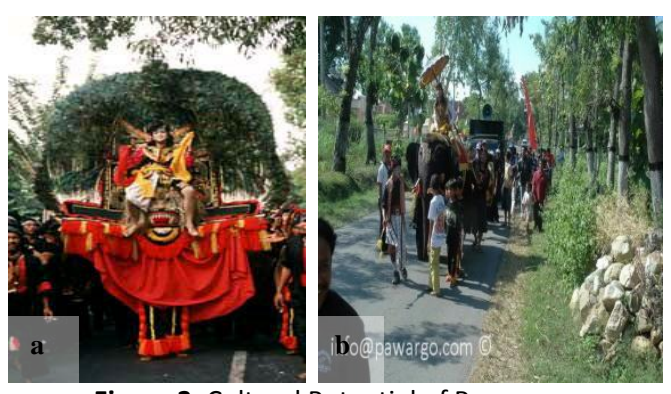

Figure 3. Cultural Potential of Ponorogo

a) Reog [9], b) Gajahan [10]

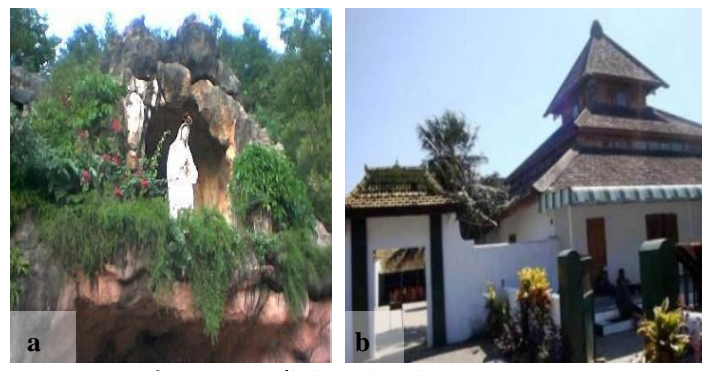

Figure 4. Religious Site in Ponorogo

a) Cave of Maria Fatima Sendang Waluya Jatiningsih for Catholics Worship in Klepu Village, Sooko District [11]

b) Tomb of Kyai Ageng Mohammad Besari, in Jami' Mosque, Tegalsari [12]

\section{Potential Culinary}

Besides famous for its Reog art, Ponorogo has the culinary Sate Ayam (Chicken Satay) and also Dawet Jabung, and Serabi (stew pancake). These menu are interesting to be tasted if tourist visiting Ponorogo (Fig. 5).

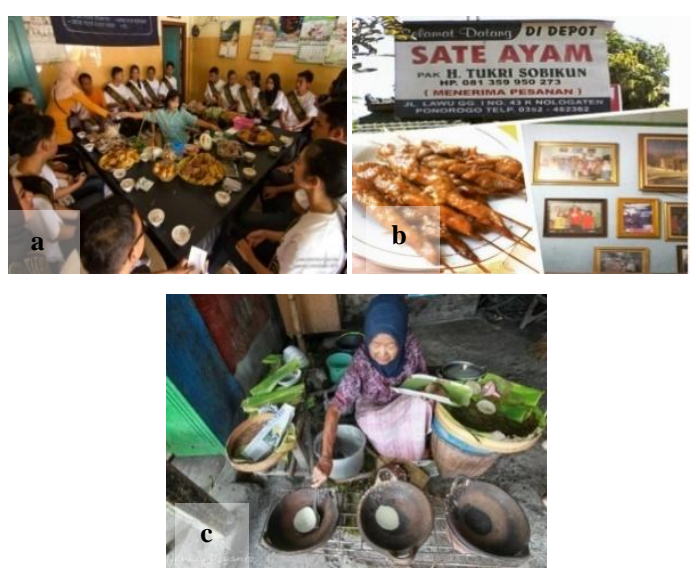

Figure 5. Cultural Potential of Ponorogo

a) Dawet Jabung HJ. Sumini (personal documentation),

b) Chicken Satay Ponorogo H. Tukri Sobikun (personal documentation), c) Serabi (stew pancake) [13]

\section{Festival and Events}

Besides the existed potential attractions that previously explained, e.g. natural resources, culture, agriculture, and culinary, the least we illustrate the amendable potential attraction and also directed easily as development model pilot of tourism in local level. Moreover, Ponorogo have various events or festivals which are scheduled annually (Table 2). Thus it is easy to describe it to the travelers. The events also featured attractions which are made to entertain Ponorogo's residents and visitors who took time to visit Ponorogo.

\section{Barrier Factors}

Factor that hampers the tourism in Ponorogo is related to the supporting access to tourism. If we review carefully, there are sectors that needs to be improved, because it is strongly affected the number of visits and comfort for tourists, i.e. transport, traffic and street lighting.

\section{Traffic and Transportation systems}

Transportation to the Ponorogo is very limited, besides the number, the quality of vehicles was also not sufficient. The problem beside unsuitable transportation is the traveling route that could not access into the tourism areas directly or along the main road only. Transportation system is considered bad. The government of Ponorogo has record that the road either in districts or village in Ponorogo Regency is bad. The access was disturbing to the local attractions.

\section{Analysis of Tourism Village in Ponorogo}

Ponorogo has prerequisite to create tourism villages, considering the potential nature resources, peculiar people characteristics, and culture. However, it is minus in some aspects, related to facilities and infrastructure of the traffic and road, as well as vehicle which is still limited and minimal.

Tourism village is rural areas that have some specific characteristic to be tourism destinations. In this area, the citizens are also has tradition and cultural, which is still relatively native. In addition, some supporting factors are special culinary, system of farming and social system also becomes diverse attractions in the tourism village. Beside these factors, nature and environment are still original and preserved well as the major tourism destinations [3]. 
Table 1. Potential Natural Resources in Ponorogo

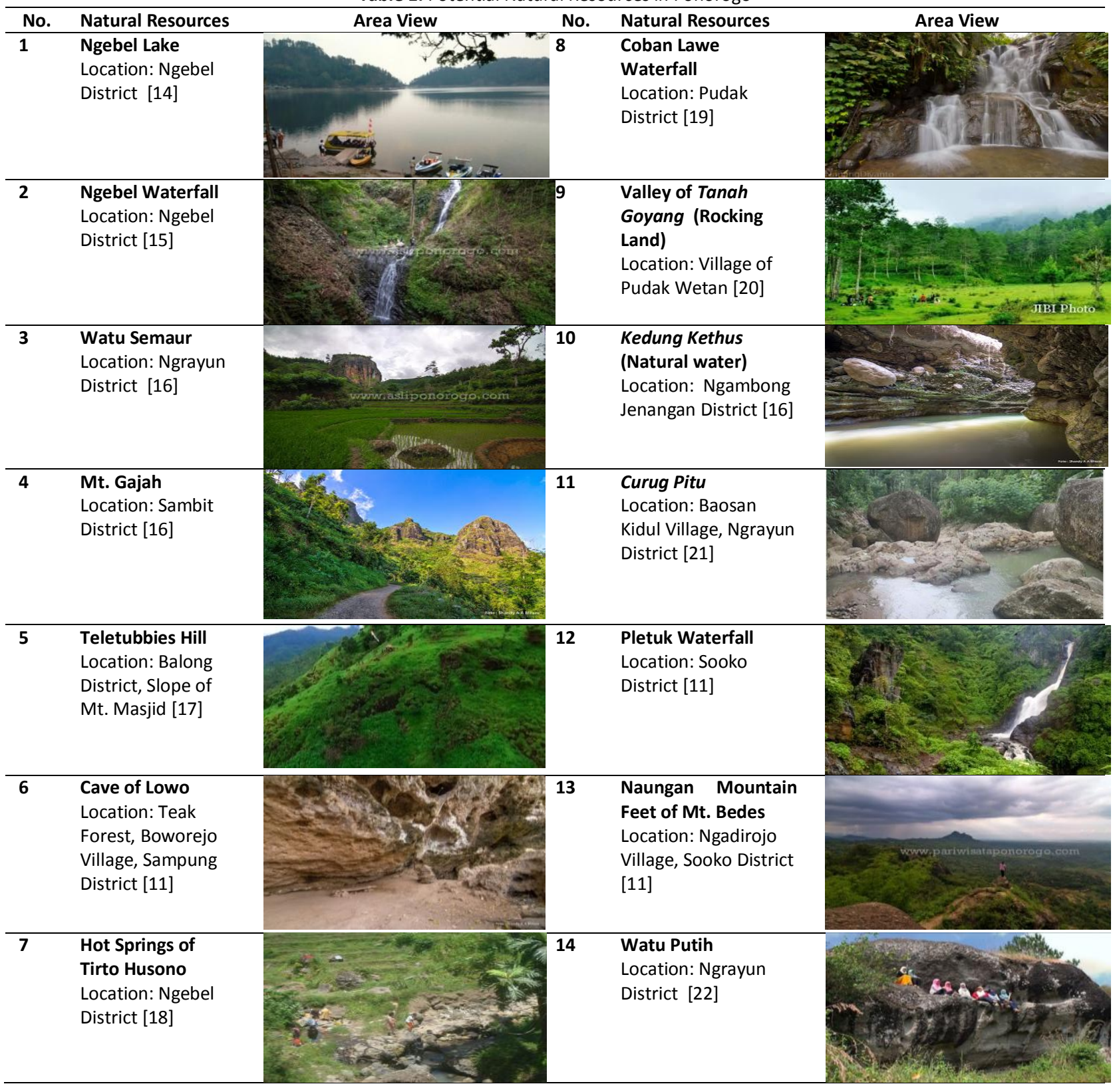

Table 2. Festival and Events in Ponorogo

\begin{tabular}{|c|c|c|c|}
\hline No. & Festival and Events & Time & Location (Districts) \\
\hline 1 & $\begin{array}{l}\text { Reog and Bulan Purnama } \\
\text { (Full moon) Dance }\end{array}$ & $\begin{array}{l}\text { Beginning or end of the } \\
\text { month }\end{array}$ & $\begin{array}{l}\text { Badengan, Sambit, Sampung, Balong, Sukorejo, Pudak, } \\
\text { Kauman, Slahung, Miarak, Babadan, Ngrayun, Siman }\end{array}$ \\
\hline 2 & Reog Telaga Ngebel & $\begin{array}{l}1^{\text {st }} \text { and } 2^{\text {nd }} \text { week of the } \\
\text { month }\end{array}$ & Ngebel, Jenangan, Pulung, Sooko, Pudak, \\
\hline 3 & Reog Bantarangi Sumoroto & $\begin{array}{l}3^{\text {rd }} \text { and } 4^{\text {th }} \text { week of the } \\
\text { month }\end{array}$ & $\begin{array}{l}\text { Sumoroto (village), Jambon, Sukorejo, Sampung, } \\
\text { Badegan, Kauman }\end{array}$ \\
\hline 4 & $\begin{array}{l}\text { Grebeg Suro - National } \\
\text { Festival of Reog Ponorogo }\end{array}$ & $\begin{array}{l}\text { Annually, } 1^{\text {st }} \text { Muharam }\left(1^{\text {st }}\right. \\
\text { Suro in Java Calendar })\end{array}$ & Main Square of Ponorogo \\
\hline 5 & $\begin{array}{l}\text { Regent Cup Road Race } \\
\text { Ponorogo }\end{array}$ & Annually, September & Conditional \\
\hline
\end{tabular}


In case of Pononogo, villages can be developed as rural tourism destination through some criteria and conditions, namely: 1). Good accessibility, thus it is easy to be visited by tourists with use various kinds of transportation means; 2). Has attraction in the form of the objects of nature, art and culture, legend, local culinary, and etc to be developed as a tourism attraction; 3 ). The society and village officers give high support for the tourism village and accept evaluation on their tourism from tourists who come to the village; 4). guaranteed security in the village; 5). provide adequate accommodation, telecommunication, and labor; 6). cool or cold temperate; 7). Closely connected with other tourism attractions that which is already well known by the public [23].

From the seven criteria, six indicators was fulfilled, thus it can be considered that Regency of Ponorogo is potential tourism destinations. Due to its objects of attraction that still natural and well maintained, thus it can be further developed.

Residents' attitudes towards tourism were positive. Positive attitudes were connected with the belief that tourism creates community development, opportunities for earning income, improved agricultural markets, and a chance at good fortune. Similar case was found in Bigodi, Uganda. In the discussion of residents' attitudes, several strategies emerged which can be used to develop an appropriate form of tourism for poor, rural people: encourage cooperatives; encourage the use of local materials and local design; target backpackers and other tourists that eager to adapt to local conditions; foster local decision making; integrate tourism with local agriculture; and use tourism revenue for community development. In Bigodi, these strategies have created positive attitudes towards tourism and an apparently increase the pro-tourism behavior [24].

\section{CONCLUSION}

The tourism development in Ponorogo, regency should emphasize on the readiness infrastructure and also superstructure to create the tourism. The tourism needs to be sustainable, thus all related parties should actively participate. In the terms of government policy, the control related to the procurement of physical development and also further supports that local attraction should be brought into a better quality.

\section{REFERENCES}

[1] Kompas. 2014. Program Nawacita Jokowi JK. Available at: http://nasional.kompas. com/read/2014/05/21/0754454/.Nawa.Cita .9.Agenda.Prioritas.Jokowi-JK.

[2] Anonymous. 2016. Map of Ponorogo. Available at: http://peta-kota.blogspot.co.id /2011/07/peta-kabupaten-ponorogo.html.

[3] Statistic Centre. 2010. Catalogue of Statistic Centre: 1101002. No 35015.003. Statistic Center of Ponorogo Regency. 2-11.

[4] Darsono. 2005. Pengertian desa. Available at: http://desasentonorejo.wordpress.com/ bab-ii/.

[5] Demartoto, A. 2009. Membangun pariwisata berbasis masyarakat. Sebelas Maret University Press. Surakarta. p. 125.

[6] Yoeti, O. 1996. Pengantar ilmu pariwisata. Angkasa Publisher. Bandung.

[7] Madiun Pos. 2016. Paddy field for the rice cultivations. Available at: http://www. madiunpos.com/2016/04/18/pertanianponorogo-petani-keluhkan-harga-gabahrendah-hanya-rp3-500kg-711307.

[8] Madiun Pos. 2016. Onion Plants. Available at: http://www.madiunpos.com/2015/12/ 09/pertanianponorogo-harga-brambangtinggi-petani-ponorogo-semringah-668822.

[9] Eastjava. 2016. Reog Ponorogo. Available at: http://www.eastjava.com/tourism/ponorog o/culture.html.

[10] Pawargo. 2016. Seni Gajahan. Available at: http://www.pawargo.com/2010/08/kesenia n-gajah-gajahan-khas-ponorogo.html.

[11] Department of Culture and Tourism Ponorogo. 2016. Ponorogo Tourism Info. Available at: http://www.pariwisatapono rogo.com/.

[12] Anwar, C. R. (Ed). Tegalsari Mosque Ponorogo. Available at: http://www.bangsaonline.com/berita/3342 /masjid-tegalsari-ponorogo-miliki-kubahtanah-liat.

[13] National Geographic Indonesia. 2016. Serabi of Ponorogo. Available at: http://national geographic.co.id/berita/2015/08/gurihnyaserabi-kuah-khas-ponorogo.

[14] Madiun Pos. 2016. Tourism in Ponorogo: Ngebel Lake. Available at: http://www. madiunpos.com/2015/10/04/wisataponorogo-ini-dia-cerita-mistis-seputartelaga-ngebel-648633.

[15] Myraza, S. A. A. 2011. Toyomerto Waterfall, Selorjo Pupus. Available at: http://www. 
asliponorogo.com/2016/02/air-terjun-

toyomerto-selorejo-pupus.html.

[16] Asli Ponorogo. 2016. Tourism in Ponorogo. Available at: http://www.asliponorogo.com.

[17] Maspamuji, A. 2016. Hill of Teletubbies. Availabel at: http://inzanami.com/bukitteletubbies-lereng-gunung-masjid-pandakbalong-ponorogo/.

[18] Sudarmawan. 2014. Potensi sumber air panas dan Air Tiga Rasa tak dikelola maksimal. Available at: http://surabaya. tribunnews.com/2014/01/01/potensisumber-air-panas-dan-air-tiga-rasa-takdikelola-maksimal.

[19] Regency Office of Ponorogo. 2015. Coban Lawe Waterfall. Available at: http:// ponorogo.go.id/air-terjun-coban-lawe/.

[20] Adhi, S. I. 2015. Liburan Unik Lembah Tanah Goyang Pandansari, Mau Coba? Available at: http://www.madiunpos.com/2015/12/ 27/wisata-ponorogo-liburan-unik-lembahtanah-goyang-pandansari-mau-coba674824.

[21] Adhi, S. I. 2016. Perawannya Jurug Pitu di Baosan Kidul mengundang anda. Available at: http://www.madiunpos.com/2016/01/ 20/wisata-ponorogo-perawannya-jurugpitu-di-baosan-kidul-mengundang-anda682590.

[22] Office of Ngrayun District. 2016. Tourism in Ngaryun, Ponorogo. Ngrayun District, Ponorogo Regency.

[23] Hakim, L. Etnobotani dan manajemen kebun-pekarangan rumah: Ketahanan pangan, kesehatan dan agrowisata. Selaras Publisher. Malang.

[24] Lepp, A. 2007. Case study residents' attitudes towards tourism in Bigodi Village, Uganda Recreation, Park and Tourism Management. Tourism Management 28, 876-885. 